Journal of Academic Value Studies (JAVStudies)

Makale geliș tarihi/Article arrival date: 09.09.2019 - Makale Kabul Tarihi/ The Published Rel. Date: 12.11.2019

BİÇKES, D. M., YILMAZ, C. (2019). "The Effect of Trust in Manager on Burnout at Schools: The Mediating Role of Organizational Identification", Journal of Academic Value Studies, Vol: 5, Issue: 5; pp: 861-879 (ISSN: 2149-8598).

\title{
THE EFFECT OF TRUST IN MANAGER ON BURNOUT AT SCHOOLS: THE MEDIATING ROLE OF ORGANIZATIONAL IDENTIFICATION*
}

\author{
Okullarda Yöneticiye Güvenin Tükenmişlik Üzerindeki Etkisi: Örgütsel \\ Özdeşleşmenin Aracılık Rolü
}

\section{Asst. Prof. Dr. Durdu Mehmet BİÇKES}

Faculty of Business Science, Nevşehir Hacı Bektaş Veli University, dmbickes@nevsehir.edu.tr, Nevşehir, Turkey

\author{
Dr. Celal YILMAZ ID
}

School of Foreign Languages, Nevşehir Hacı Bektaş Veli University, cyilmaz@nevsehir.edu.tr, Nevşehir, Turkey

\section{ABSTRACT}

\section{Anahtar Kelimeler \\ Duygusal Tükenme, Duyarsızlașma, \\ Kișisel Başarı, \\ Yöneticiye Güven, \\ Özdeşleşme,}

\section{Keywords}

Emotional Exhaustion, Depersonalization, Personal Accomplishment, Trust İn Manager, Identification,
This study aims to investigate the relationship between trust in manager and burnout and the mediation role of organizational identification. Structural equation modelling (SEM) was used to analyze data from 272 high school educators (teachers and principals) in Nevşehir/Turkey. In terms of the findings, it is seen that the findings entirely support the research model. Trust in manager significantly affects organizational identification. The direct effect of trust in manager on burnout is also significant. The findings posit that the effect of trust in manager on burnout is fully mediated by organizational identification. Futhermore, theoretical and managerial implications and future research directions are suggested with some limitations in the study. For example, school attractiveness, well-clarified school identity, shared and common objectives, integration with school can play an important role to reduce teachers' burnout level. The value of the study is that it proposes a model, showing full mediation role of organizational identification between trust in manager and burnout so it contributes to the literature about these three variables as the mediation role of organizational identification on the relationship between trust in manager and burnout has not been seen in the literature.

\section{ÖZ}

Bu çalışmanın amacı, yöneticiye güven ile tükenmişlik arasındaki ilişkiyi ve bu ilişkide örgütsel özdeşleşmenin aracılık rolünü araştırmaktır. Nevşehir/Türkiye'deki liselerde görev yapmakta olan 272 eğitimciden (öğretmenler ve idareciler) elde edilen veriler yapısal eşitlik modeli (YEM) ile analize tabi tutulmuştur. Çalışma bulgularının önerilen modeli tamamen desteklediği tespit edilmiştir. Bu doğrultuda yöneticiye güven örgütsel özdeşleşmeyi anlamlı bir şekilde etkilemektedir. Yöneticiye güvenin tükenmişlik üzerindeki direk etkisi de anlamlıdır. Bulgular örgütsel özdeşleşmenin, yöneticiye güven ile tükenmişlik arasındaki ilişkide tam aracı rol üstlendiğini göstermektedir. Çalışmada teorik ve yönetsel çıkarımlarla birlikte gelecek çalışmalara öneriler ve çalışmanın kısıtlılıklarına da yer verilmiştir. Örneğin, okulun çekiciliği, iyi belirlenmiş okul kimliği, paylaşılan ortak amaçlar ve okulla entegrasyon öğretmenlerin tükenmişlik düzeylerini azaltmada önemli rol oynamaktadır. Çalıșmanın katkısı yöneticiye güven ile tükenmișlik arasındaki ilișkide örgütsel özdeșleșmenin tam aracılık rolü üstlendiğini gösteren bir model sunmasıdır. Örgütsel özdeşleşmenin söz konusu değişkenler arasındaki ilişkide aracılık

*This study was adapted from the master thesis, the mediating effect of perceived organizational identification on the relationship between organizational trust and burnout: An empirical study, carried out by Celal Yılmaz under the supervision of Asst. Prof. Dr. Durdu Mehmet Biçkes at MBA, Institute of Social Sciences, Nevsehir Haci Bektas Veli University. 
rolüne irdeleyen bir çalışmaya rastlanmamış olması bu anlamda çalışmanın literatüre katkı sağlayacağına dair düşüncemizi güçlendirmektedir.

\section{INTRODUCTION}

Burnout is one of the issues discussed in the organizational behavior literature owing to its effects on individual and organizational life. The term, burnout, was first introduced in organizational behavior literature in the 1970s by Freudenberger (1974) and Maslach (1976). Burnout refers to "continuous and increasing energy loss, motivation disorder, and indifference to work up to the point of exhaustion" (De Francisco et al., 2016, p. 240). Burnout is also defined by Maslach and Jackson (1981, p. 99) as "emotional exhaustion, depersonalization and diminishing personal accomplishment syndrome", which occurs among employees due to overly demanding and stressful working conditions that exceed an individual's coping capacity and results in failure of idealized expectations. This syndrome hinders the realization of individual and organizational goals (Sirén et al., 2018).

Empirical studies show that burnout has many negative reflections to both individual and organizational success (Shen et al., 2015; Rabasa et al., 2016; Salvagioni et al., 2017; Skaalvik and Skaalvik, 2017). Burnout is a concern for nearly all employees, but is more common in individuals who practise the vocations involving face-to-face interaction with people. One of these vocational areas is teaching (Korunka et al., 2010, p. 14). Educational activities carried out by teachers have an undeniable effect and importance on social life and economic activities (Haque, 2014). Thus, it is crucial to identify and manage the factors that will affect the individual performance of teachers. And, a number of measures should be taken to lessen or eliminate them.

Individual, organizational and environmental factors are effective on teachers' interactions with other parties and individual performances in education world. These are leadership (Kauts and Sharma, 2017), management style (Hashemi and Kohestani, 2016), talent management (Wadhwa and Tripathi, 2018), organizational justice (Cohen and Eyal, 2015), psychological empowerment (Lee and Nie, 2017), stress (Richardsen and Burke, 1995), burnout (Maslach et al., 2001), organizational trust (Edwards, 2006), cynicism, organizational commitment, organizational citizenship behavior (Özan and Özdemir, 2013) and organizational identification (Mael and Ashforth, 1992; Karabey and İşcan, 2007). Therefore, within the scope of this study, we focus on trust, identification and burnout.

One of the factors affecting burnout is organizational trust. Organizational trust involves the acceptance of any risks about the issues related to vulnerability, uncertainty, interdependence needs and trust problems. It emerges as a determining factor in achieving both individual and organizational goals and composed of trust in colleagues, managers and ultimately the organization. Trust in manager is expressed as a structure based on trustworthiness, justice, goodwill and benevolence of managers (Dyer and Chu, 2003). The environment created by establishing trust in manager within the organization reduces the burnout levels of employees and provides a more positive working environment (Ceyanes, 2004, p. 129). Therefore, while the burnout level of employees with high trust levels decreases (Van Maele and Van Houtte, 2015), information sharing, organizational support, organizational identification and performance levels increase (Fulmer and Gelfand, 2012).

Another factor affecting burnout is organizational identification. According to Dutton et al., (1994) organizational identification is the use of similar and shared expressions prefered by individuals in defining both themselves and their organization. The findings of various studies show that organizational identification has positive effects on increasing positive organizational behaviors and decreasing negative organizational behaviors (O'Neill and Gaither, 2007; Edwards and Peccei, 2010). Through organizational identification, employees' job satisfaction, organizational commitment, occupational and group commitment, business entrepreneurship, organizational loyalty and extra role behaviors increase, and their intentions to leave reduce (Riketta, 2005; Riketta and Van Dick, 2005). In addition, individuals and groups with organizational identification are likely to make more efforts to achieve group and organizational success (Levine et al., 2005). Besides, they are less likely to be exposed to the effects of performance reducing factors such as burnout and cynicism (Maslach and Leiter, 2008; Rode et al., 2012; Avanzi et al., 2015).

Organizational identification is one of the consequences of organizational trust. The relationship between organizational trust, trust in manager, trust in leader and organizational identification have 
been studied in the literature (Lee, 2004; Edwards and Cable, 2009; Agarwal, 2013; Khattak et al., 2014). However, the mediation role of organizational identification in the relationship between trust in manager and burnout has not been found in the literature review although organizational identification have been examined as a mediator in various studies (Fu et al., 2014; Morçin and Çarıkçı, 2016). So we argue that organizational identification may mediate the relationship between trust in manager and burnout.

In the light of this information, this study aims to investigate the effect of trust in manager on burnout and the mediating impact of organizational identification on the relationship between trust in manager and burnout. For this purpose, firstly, the literature was reviewed and the variables of the study and the relationships between these variables were searched within the framework of theoretical and empirical studies in literature. Secondly, scales, sampling, data collection method and data analysis techniques were given in the methodology section. Finally, the research findings, results and suggestions are depicted in the last part.

\section{THEORETICAL BACKGROUND}

\section{1. Organizational Identification}

Organizational identification, which is a specific form of social identification, shows how individuals define themselves in terms of their membership of a particular organization (Mael and Ashfort, 1992; Haslam, 2004, p. 217). Similarly, individuals with a high organizational identification use similar expressions to define both themselves and their organizations (Dutton et al., 1994). Organizational identification results in individual internalization of organizational policies, norms and values. Through the organizational identification, the identity limit between the individual and the organization becomes blurred. Individuals with organizational identity, as the microcosm of the organization, exhibit attitudes and behaviors that benefit the organization, rather than focusing on their personal interests (Lee et al., 2015). Organizational identification is based on three principles: identification as belongingness, identification as loyalty and identification as shared characteristics. Identitification as belongingness is the situation where the individual perceives his/her functions in the organizational activities as necessary to meet his/her needs. This situation occurs as a result of the match between organizational goals with the individual goals and prepares the grounds for individuals to feel belongingness to their organizations. Identification as loyalty is the situation where the individual adopts and supports organizational goals and exhibits attitudes and behaviors such as feeling proud of the organization or defending the organization in the external environment. Identitfication as shared characteristics refers to the similarities between the individual and the other members in the organization. "Shared characteristics are composed of demographic, attitudinal and organizational variables such as educational qualifications, experience, gender, race, age, tenure, type of work" (Lee, 1971, pp. 214-215).

Organizational identification is the result of an individual's perception of himself/herself as united with the organization, because of the feeling of organizational belongingness and defining himself/herself within the context of organization as being a member of it. From this point of view, organizational identification may be considered as a developed situation in terms of shared destiny and meaning (Mael and Ashforth, 1992). In addition, it may be suggested that organizational identification stems from a need to build social identity. The individual increasingly embarks on a guest of meaningful organization membership when she/he needs a high level of organizational identification. Thus, the need for organizational identification not only leads the individual to be a part of the organization, but also supports the individual's self-esteem (Mignonac et al., 2006).

High level of organizational identification breeds internalizing organizational goals, feeling of organizational belongingness, identifying himself/herself in parallel with his/her organizational identity, sharing the same or similar characteristics with other members of the organization, establishing a similar destiny with the organization in terms of his/her own goals and exhibiting behaviours to defend the organization against others (Biçkes and Yllmaz, 2017). High level of organizational identification results in higher job satisfaction, more organizational citizenship behavior, more employee satisfaction and performance (Karabey and Iscan, 2007), higher business inputs (Lee, 1971), and less intention to leave (Wegge et al., 2006). 


\section{2. Burnout}

Burnout was introduced to the literature in the book 'Staff Burnout' by Freudenberger (1974). It is more commonly observed in employees who perform their work interacting intensely with people although it may be seen in all jobs (Maslach and Schaufeli, 2017, p. 12). Maslach and Jackson (1981) express that it is emotional exhaustion and cynicism syndrome, which are frequently seen in individuals who intensively interact with people. In another source, the concept is expressed as "the feeling of exhaustion due to diminishing personal accomplishment or diminishing performance" (Korunka et al., 2010, p. 7). Burnout, which causes various erosions on the individual's virtue, soul, desire and self-esteem, is likened to a disorder that destroys the effectiveness of an individual in time (Maslach and Leiter, 2008, p. 17).

Burnout is a syndrome that occurs as a result of reaction to various factors in a long time period (Biçkes and Yılmaz, 2017). Excessive workload and adverse working conditions are particularly effective in the development of burnout. The energy and efficiency of the individuals working in such environments decrease and the emotional exhaustion process develops. The individual gradually starts to estrange himself from his work, his work environment and his colleagues. Following this phase, the individual begins to feel depersonalized to the work and the service recipients. In the end, the individual faces a worse process where personal accomplishment decreases or where inefficacy emerges (Maslach and Leiter, 2017). It is understood from these statements that burnout is a syndrome composed of several phases. These phases are the core areas that eventually reveal burnout and are known as burnout dimensions. Maslach and Jackson (1981, p. 99) clarify these dimensions as "emotional exhaustion, depersonalization and reduced personal accomplishment".

Emotional exhaustion is a chronic emotional and physical exhaustion. Individuals who are emotionally exhausted due to their work and chronic stressors feel themselves fatigue or exhausted (Baer et al., 2015, p. 1640). Depersonalization is defined as "loss of motivation against work, withdrawal and cynicism" (Bianchi et al., 2015, p. 216). In this process, the employee starts to behave indifferently against the service recipients, takes a cynical attitude and the constructive interaction with people gradually fades away (Maslach et al., 2001, p. 403). In later phases, depersonalization has serious effects on the individual's psychological well-being and effectiveness (Maslach and Leiter, 2008, p. 18), and his personal accomplishment begins to reduce. Individual is unable to respond to chronic overwhelming work demands. Consequently, the individual's sense of self-activity melts and the individual becomes inefficient at work (Maslach et al., 2001). Furthermore, colleagues lose their confidence in his/her abilities in these phases (Maslach and Leiter, 2008, p. 18).

\section{3. Trust in Manager}

Organizational trust is defined as being able to take rational decisions and exhibit strategic behaviors in situations involving risk and vulnerability (Cohen and Dienhart, 2013: 1). Organizational trust, therefore, requires broad relational vigilance, openness, commitment and respect (Dovey, 2009). In the literature, organizational trust is divided into three dimensions as trust in manager, trust in organization and trust in colleagues and also it is dimensioned as calculus-based, knowledge-based and identification-based (Lewicki and Bunker, 1996, pp.119-124). This study focuses on trust in managers from these dimensions. Trust in manager is the consent of the party to be vulnerable during and after the work and relationship and the expectation of the party representing that the manager will act in accordance with principles, resposibilities and common interests (Mayer et al., 1995; Mishra, 1996; Rousseau et al., 1998).

Managers need to have a number of individual characteristics such as trustworthy intentions, fairness, loyalty, openness, benevolence, competence and high foresight in order to establish trust in manager (Mayer et al., 1995). In addition, managers should also exhibit positive behaviors such as consistency and integrity in their behavior, sharing and distribution of control, true and open communication, attention and care for employees (Tan and Tan, 2000; Dyer and Chu, 2003). Another point of trust in the manager is that the manager should know the employees. It is suggested that it may be possible to establish mutual trust through the use of knowledge about employees if the manager is able to obtain information about their skills, needs, targets and interest areas. Trust in manager results in satisfaction with the manager, performance, innovative behaviors and extra efforts for organizational goals (Braun et al., 2013; Özafşarlığlu Sakallı and Örücü, 2017). Employees may be reluctant even to 
fulfill the minimum performance requirements when trust is low (Brower, et al., 2009).

\section{4. Relationship Between Trust in Manager, Burnout and Organizational Identification: Hypotheses Development}

\section{4. 1. Trust in Manager and Organizational Identification}

Trust is the vulnerability of the party based on his/her positive expectations about the other party's intentions and behaviors in any relations (Mayer et al., 1995). Organizational identification, on the other hand, emerges from the association of both the individual's goals and organization's goals (Edwards, 2006). From this point of view, it is possible to argue that the main premise of the realization of organizational goals is adoption of these objectives by employees. Therefore, it is also possible to claim that organizational identification breeds from organizational trust. In the literature, many studies examine the relationship between both variables (Connaughton and Daly, 2004; Edwards and Cable, 2009; Agarwal, 2013; Tokgöz and Seymen, 2013). In these studies, there is a significant and positive correlation between trust in manager and organizational identification (Connaughton and Daly, 2004; De Cremer and van Knippenberg, 2005; Agarwal, 2013). Similarly, studies show that there is a significant and positive relationship between cognitive-based and emotional-based trust in manager and organizational identification (Tüzün and Çağlar, 2009; Ertürk, 2010; Schaubroeck et al., 2013). In the light of these explanations, the following hypothesis is developed.

H1: There is a significant and positive relationship between trust in manager and organizational identification.

\section{4. 2. Trust in Manager and Burnout}

Trust climate in the organization reduces the burnout levels of the employees and provides a more positive working environment (Ceyanes, 2004, p. 129). Ellonen, et al (2008, s.163) argue that interpersonal trust (trust between manager and employee) plays a crucial role on the well being of employees. Burnout is a syndrome affecting employees' well being, self esteem, soul and motivation (Maslach and Leiter, 2008, p.17). Some studies' findings also reveal the relationship between trust in manager and burnout. For example, Harvey et al. (2003) report a negative relationship between trust in management and burnout. In addition, employees showing low trust in managers in an organization may experience higher levels of burnout (Ceyanes, 2004; Özan and Özdemir, 2013). Bobbio et al. (2012) state that trust in leader and organizational trust negatively affect emotional exhaustion. Çağlar (2011) and Son et al. (2014) find a significant and negative relationship between trust in manager and emotional exhaustion and depersonalization in their studies. However, it is seen that there is a positive and significant relationship between trust in manager and personal accomplishment (Çağlar, 2011). Therefore, this leads to next hypothesis.

H2: Trust in manager affects negatively a) emotional exhaustion, and b) depersonalization but positively c) personal accomplishment.

\section{4. 3. Organizational Identification and Burnout}

There are two basic approaches on the relationship between identification and burnout. In the studies that consider organizational identification as an antecedent of burnout, due to hard work and overwhelming workload (Ashforth et al., 2008), it is suggested that individuals who experience high levels of organizational identification may experience more burnout than individuals with low levels of organizational identification (Maslach et al., 2001). From this point of view, it is possible to suggest that it is necessary to keep the organizational identification level at an optimal point. On the other hand, there are also some studies showing that organizational identification increases job satisfaction (Wegge et al., 2006), provides more work inputs and diminishes intention to leave (Lee, 1971) and reduces burnout (Maslach and Leiter, 2008: 17). In this study, organizational identification is regarded as a variable that causes various positive organizational outcomes and that has negative effects on burnout.

The studies focusing on the relationship between organizational identification and burnout show that organizational identification negatively affects burnout (Rode et al., 2012), emotional exhaustion (Avanzi et al., 2015; Kemp et al., 2013; Lammers et al., 2013) and depersonalization (Wegge et al., 
2006; Lammers et al., 2013). On the other hand, there are differences in the findings of the relationship between organizational identification and personal accomplishment because some studies deal with personal accomplishment as reduced personal accomplishment. Therefore, the findings of these studies show that there is a negative relationship between organizational identification and reduced personal accomplishment (Avanzi et al., 2015). The other studies that consider it as personal accomplishment suggest that organizational identification positively affects it (Wegge et al., 2006). So the following hypothesis is developed based on these studies.

H3: Organizational identification affects negatively a) emotional exhaustion and b) depersonalization but positively c) personal accomplishment.

\section{4. 4. Mediating Role of Organizational Identification}

Within our literature review, no study has been found to address the mediating role of organizational identification in the relationship between trust in manager and burnout. However, some studies focus on the mediating role of organizational identification in the relationship between various variables (Tokgöz and Seymen, 2013; Fu et al., 2014; He et al., 2014; Moriano et al., 2014; Morçin and Çarıkçı, 2016). Burnout is one of the important factors that negatively affect the work resources (Blankertz and Robinson, 1997). Besides, organizational trust perceptions have a negative effect on the level of burnout (Fulmer and Gelfand, 2012). It is also certain that organizational identification decreases the level of burnout (Maslach and Leiter, 2008, p. 17). Thus, it is possible to suggest that both trust in manager and organizational identification will play a role in reducing the effects of burnout. In addition, one of the consequences of trust in manager is organizational identification (Edwards and Cable, 2009). Therefore, in this study, it is believed that organizationl identification will have a mediating role in the relationship between trust in manager and burnout. Based on these observations, the following hypothesis is developed:

H4: Organizational identification mediates the relationship between trust in manager and a) emotional exhaustion, b) depersonalization and c) personal accomplishment.

\section{METHODOLOGY}

\section{1. Instrument}

A questionnaire was created that contains three basic constructs relating to burnout, organizational identification and trust in manager. Each of these constructs was measured using a five-point Likerttype scale $(1=$ strongly disagree and $5=$ strongly agree). To measure burnout, 22 items created by Maslach and Jackson (1981) were used; nine items for emotional exhaustion, five for depersonalization and eight for personal accomplishment. The items of burnout scale were translated and adapted into Turkish and its validity and reliability were conducted by Ergin (1992). To measure organizational identification, seven items created by Van Dick et al., (2004) were used. This scale was used in various Turkish studies and its validity and reliability were analyzed (Karabey and İșcan, 2007; Ylldız, 2012). Finally, to measure trust in manager, eight items created by Nyhan and Marlowe (1997) were used. The scale was adapted into Turkish by Demircan (2003) and used in various studies in Turkish (Eğriboyun, 2013; Esitti ve Akyüz, 2015).

\section{2. Data Collection and Sample}

The population of the study was composed of 1210 teachers and principals working in the high schools in Nevşehir/Turkey in 2013-2014 education periods, based on the web site of Nevşehir Provincial Directorate for National Education (Nevşehir İl Milli Eğitim Müdürlüğü, 2014). The sample size was determined through the formula, $n=N t^{2} p q / d^{2}(N-1)+t^{2} p q$ (Yazıcıoğlu and Erdoğan, 2004: 48). It shows that the sample size is $124(\mathrm{~N}=1210 ; \mathrm{p}=0.9 ; \mathrm{q}=0.1 ; \mathrm{t}=1.96$; sampling error=5\%, reliability=95\%). About sample size adequacy, Hair et al. $(2013$, p. 100) emphasize that "...the minimum is to have at least five times as many observations as the number of variables to be analyzed, and the more acceptable sample size would have a 10:1 ratio". The scales of this study consist of 37 items. So, sample size should have at least 185 and more acceptable 370 cases. Convenience sampling method was preferred in the study due to the situations such as teachers' rotation, daily lack of classes, sickness or days off. Of the teachers encountered in the teachers' room, 290 participated in the study. After excluding 18 inadequate and invalid questionnaires, a total of 272 provided usable 
questionnaires. Participant rate of the population is $22.47 \%$. In addition, at least a $20 \%$ response rate is recommended in studies where the population is large (Kitchenham and Pfleeger, 2002). As a result, it is inferred that the sample size is adequate.

Of the 272 teachers and principals who participated in the study, $42.3 \%$ are women and $57.7 \%$ are men. While $82 \%$ of the participants are married, $18 \%$ are single. In addition, most of the participants (83.4\%) fall into the age froup ranging from 26 to 45. In terms of work experience, the highest portion $(25 \%)$ is in 6-10 year experience-range. $86 \%$ of participants are teachers and $14 \%$ of them are principals or vice principals. When their teaching branches are analyzed, it is seen that $48.9 \%$ of the participants teach verbal, $28.3 \%$ maths/science, $19.1 \%$ vocational courses, and $3.7 \%$ fine arts. Finally, in terms of school types where they are employed, majority of them (57.4\%) work in vocational high schools, 23.9\% in Anatolian high schools, 10.3\% general high schools, 4\% science high schools and $4.4 \%$ in other high schools.

\section{3. Data Analysis}

To test the hypotheses of this study, structural equation modeling (SEM) was used. Firstly, extreme outliers were identified through Mahalanobis distance test. According to Hair et al. (2013, p. 65), outliers of which ratio is over 3 or 4 may be removed from the analysis. In the first analysis, it was found that the highest Mahalanobis distance ratio was less than 3 (Mahalanobis D> 99.634 / $37=2.69$; $\mathrm{p}<.001$ ). Therefore, no outlier was removed in the data set. Then skewness and kurtosis tests were conducted to test the multivariate normal distribution (Schumacker and Lomax, 2016, p. 35). Skewness and kurtosis values should be between critical values between $+-2.58 ; \mathrm{p}<.01$ and between +-1.96 ; $\mathrm{p}<.05$ (Hair et al., 2013, p. 71). According to this test, it was found that the skewness values were between $(-1.182$ and $1.418 ; \mathrm{p}<.01)$, the kurtosis values were between $(2.535$ and $-1.059 ; \mathrm{p}<.01)$. So, it was decided that the data set was normally distributed (Kline, 2011, p. 160).

Trust in manager and organizational identification are one-dimensional scales. The common method bias (CMB) was analyzed for burnout and it was seen that just a single factor did not occur and just a single factor did not explain a large part of the total variance (Podsakoff and Organ, 1986). In order to determine the relationship between variables of the study, a two-stage approach, the measurement model and the structural model, were preferred (Anderson and Gerbing, 1988). Bootstrap confidence intervals method was used for mediation test (Hayes, 2013, p. 197).

\section{FINDINGS}

\section{1. Measurement Model}

It is possible to analyze the single and collective performance of the observed variables, the nature and structure of the latent phenomena and the number of dimensions through confirmatory factor analysis (CFA) (Bowen and Guo, 2011, p. 9-10). According to the two-stage SEM approach, firstly, CFA was conducted (Anderson and Gerbing, 1988). Following the recommendations of Hair et al. (2013, p. 103), items of which factor loading is less than 0.50 were severally removed from the analysis. Finally, four organizational identification, one trust in manager and six burnout items were removed.

First of all, the measurement model, which is the first step of SEM, has been tested. Therefore, fit indices and construct validity (discriminant and convergent validity) have been examined (Hair et al., 2013, p. 605). These findings are presented in Table 1.

Goodness-of-fit statistics, $\chi 2$ /df, IFI, CFI, GFI, RMSEA are reported based on studies by Byrne (2010, p. 126) and Kline (2016, p. 269). As seen in Table 1, the goodness-of-fit indices of the measurement model $(\chi 2 / \mathrm{df}=2.200 ; \mathrm{IFI}=.91 ; \mathrm{CFI}=.91 ; \mathrm{GFI}=.85$; $\mathrm{RMSEA}=.067)$ are within the acceptable limits (Schermelleh-Engel et al., 2003). Convergent validity and discriminant validity were checked for construct validity. So, factor loading values and AVE values were analyzed for convergent validity. Accordingly, it is determined that the factor loadings and AVE values of the dimensions are all above the recommended minimum value of 0.50 . Construct reliability (CR) values are also higher than 0.70 . Consequently, these values ensure that there is adequate convergent validity (Diamantopoulos and Siguaw, 2000, p. 90; Hair et al., 2013). Discriminant validity is based on correlation rates between latent variables. In order to identify the discriminant validity, the AVE value of each latent variable must exceed the square of the correlation value with another factor (Fornell and Larcker 1981, p. 46; 
Hair et al., 2013, p. 605). In other words, the OAV squareroot of each latent variable (cross-bold values in Table 1) is higher than the correlation between two variables for the both relevant factors (Gaskin and Lim, 2016). Therefore, it is ensured that there is adequate discriminant validity between the latent variables.

Table 1. Measurement Model

\begin{tabular}{|c|c|c|c|}
\hline $\begin{array}{l}\text { First- } \\
\text { order } \\
\text { Variables }\end{array}$ & Items & SFL & t values \\
\hline \multirow{3}{*}{$\overline{0}$} & $\begin{array}{l}\text { I identify myself as a member of my school in every environment, } \\
\text { both at the school and in the external environment. }\end{array}$ & .691 & * \\
\hline & $\begin{array}{l}\text { Being a member of my school reflects my personality well in } \\
\text { terms of its culture, values and goals. }\end{array}$ & .813 & 11.022 \\
\hline & I like working at my school. & .794 & 10.892 \\
\hline \multirow{7}{*}{$\sum_{E}$} & $\begin{array}{l}\text { At our school, the principals are technically competent at the } \\
\text { critical elements of their jobs. }\end{array}$ & .724 & * \\
\hline & $\begin{array}{l}\text { At our school, the principals will make well thought out decisions } \\
\text { about their jobs. }\end{array}$ & .782 & 12.579 \\
\hline & $\begin{array}{l}\text { I feel high level of confidence that the principlas have an } \\
\text { acceptable level of understanding of their job. }\end{array}$ & .822 & 13.233 \\
\hline & $\begin{array}{l}\text { I feel high level of confidence that the principlas will be able to do } \\
\text { their job in an acceplable manner. }\end{array}$ & .776 & 12.480 \\
\hline & $\begin{array}{l}\text { When the principals tell me something, I have no doubt about } \\
\text { what they tell me. }\end{array}$ & .703 & 11.269 \\
\hline & $\begin{array}{l}\text { I feel high level of confidence that the principlas do the job } \\
\text { without causing other problems. }\end{array}$ & .836 & 13.459 \\
\hline & $\begin{array}{l}\text { I feel high level of confidence that the principlas will follow } \\
\text { through on assignments. }\end{array}$ & .799 & 12.853 \\
\hline \multirow{7}{*}{ 뙫 } & I feel emotionally drained from my work. & .641 & * \\
\hline & I feel used up at the end of the workday. & .770 & 10.667 \\
\hline & $\begin{array}{l}\text { I feel fatigued when I get up in the morning and have to face } \\
\text { another day on the job. }\end{array}$ & .767 & 10.630 \\
\hline & Working with students all day is really a strain for me. & .749 & 10.439 \\
\hline & I feel burned out from my work. & .857 & 11.532 \\
\hline & I feel frustrated by my job. & .696 & 9.853 \\
\hline & Working with students directly puts too much stress on me. & .701 & 9.905 \\
\hline \multirow{3}{*}{ 吕 } & I feel I treat some students as if they were impersonal 'objects'. & .620 & * \\
\hline & I've become more callous toward students since I took this job. & .895 & 10.830 \\
\hline & I worry that this job is hardening me emotionally. & .869 & 10.807 \\
\hline \multirow{4}{*}{ 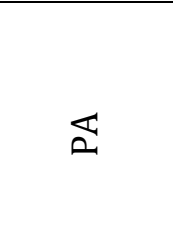 } & I feel I'm positively influencing students' lives through my work. & .732 & * \\
\hline & I feel very energetic. & .709 & 11.115 \\
\hline & In my work, I deal with emotional problems very calmly. & .570 & 8.904 \\
\hline & I can easily create a relaxed atmosphere with my students & .829 & 12.931 \\
\hline
\end{tabular}


I feel exhilarated after working closely with my students.

.793

12.411

I have accomplished many worthwhile things in this job.

.644

10.074

\begin{tabular}{|c|c|c|c|c|c|c|c|}
\hline \multicolumn{8}{|c|}{ Discriminant and convergent validity and correlations } \\
\hline $\mathrm{CR}$ & & AVE & OI & TM & $\mathrm{EE}$ & DP & $\mathrm{PA}$ \\
\hline OI & 0.811 & 0.589 & 0.768 & & & & \\
\hline $\mathrm{TM}$ & 0.915 & 0.606 & $0.589 * *$ & 0.779 & & & \\
\hline $\mathrm{EE}$ & 0.895 & 0.552 & $-0.420^{* *}$ & $-0.277^{* *}$ & 0.743 & & \\
\hline $\mathrm{DP}$ & 0.843 & 0.647 & $-0.280^{* *}$ & $-0.170^{*}$ & $0.516^{* *}$ & 0.804 & \\
\hline PA & 0.863 & 0.515 & $0.486^{* *}$ & $0.367^{* *}$ & $-0.377^{* *}$ & $-0.362^{* *}$ & 0.718 \\
\hline
\end{tabular}

Goodness- of- fit statistics: $\chi 2 / \mathrm{df}=2.200 ; \mathrm{IFI}=.91 ; \mathrm{CFI}=.91 ; \mathrm{GFI}=.85 ; \mathrm{RMSEA}=.067 .{ }^{*}$ Parameter fixed at1.0 Cross bold values represent squareroot of AVE. Correlation (r): ${ }^{* *} p<.001 ;{ }^{*} p<.05$. CR: Construct reliability, AVE: Avarage varience extracted, OI: Organizational identification, TM: Trust in manager, EE: Emotional exhaustion, DP: Depersonalization, PA: Personal accomplishment

\section{2. Structural Model}

SEM is used to test the model and hypotheses developed within the scope of research after the measurement model analysis. The results of the SEM are depicted in Figure 1 and presented in details in Table 2. It is found that goodness-of-fit statistic values meet the acceptable limits $(\chi 2 / \mathrm{df}=2.373$; IFI $=.90 ; \mathrm{CFI}=.90 ; \mathrm{GFI}=.84 ; \mathrm{RMSEA}=.071$ ).

Table 2. Structural Model Results

\begin{tabular}{llllll}
\hline Hypotheses & Relations & $\begin{array}{l}\text { Std. factor } \\
\text { Loadings }(\beta)\end{array}$ & t values & $\mathrm{R}^{2}$ & Result \\
\hline$H 1$ & TM $\rightarrow$ OI & $.599^{* *}$ & 7.891 & .36 & Supported \\
$H 2 a$ & TM $\rightarrow \mathrm{EE}$ & .015 & .187 & & Not supported \\
$H 2 b$ & $\mathrm{TM} \rightarrow \mathrm{DP}$ & .062 & .714 & & Not supported \\
$H 2 c$ & TM $\rightarrow \mathrm{PA}$ & .081 & .988 & & Not supported \\
$H 3 a$ & OI $\rightarrow \mathrm{EE}$ & $-.487^{* *}$ & -4.900 & .23 & Supported \\
$H 3 b$ & OI $\rightarrow \mathrm{DP}$ & $-.377^{* *}$ & -3.815 & .12 & Supported \\
$H 3 c$ & OI $\rightarrow \mathrm{PA}$ & $.477^{* *}$ & 4.997 & .28 & Supported
\end{tabular}

Goodness- of- fit statistics: $\chi 2 / \mathrm{df}=2.373$; IFI=.90; CFI=.90; GFI=.84; RMSEA=.071. OI: Organizational identification, TM: Trust in manager, EE: Emotional exhaustion, DP:

Depersonalization, PA: Personal accomplishment ${ }^{* *} \mathrm{p}<.001$.

Trust in manager positively and significantly affects organizational identification as seen in Table 2 $(\beta=.599 ; t=7.891 ; p<.001)$. Therefore, this finding supports Hypothesis 1 . On the other hand, when organizational identification was included in the model, it was seen that the effect of trust in manager on burnout was not significant and Hypotheses 2a, $2 b$ and $2 c$ were not supported. Here, it is concluded that trust in manager is not effective in reducing the negative effect of emotional exhaustion and depersonalization on the employees. Moreover, trust in manager does not have a significant effect in increasing personal accomplishment. Organizational identification negatively affects emotional exhaustion and depersonalization $(\beta=-.487 ; \mathrm{t}=-4.900 ; \quad \mathrm{p}<.001 ; \quad \beta=-.377 ; \mathrm{t}=-3.815 ; \quad \mathrm{p}<.001)$. Furthermore, it is seen that organizational identification has a positive and significant effect on personal accomplishment $(\beta=.477 ; \mathrm{t}=4.997 ; \mathrm{p}<.001)$. These findings confirm that Hypotheses $3 \mathrm{a}, 3 \mathrm{~b}$ and $3 c$ are supported. As seen in Figure 1, trust in manager and organizational identification reasonably explain the dependent variables; emotional exhaustion (23\%), depersonalization (12\%) and personal accomplishment (28\%), respectively. Organizational identification is highly explained by 
trust in manager (36\%).

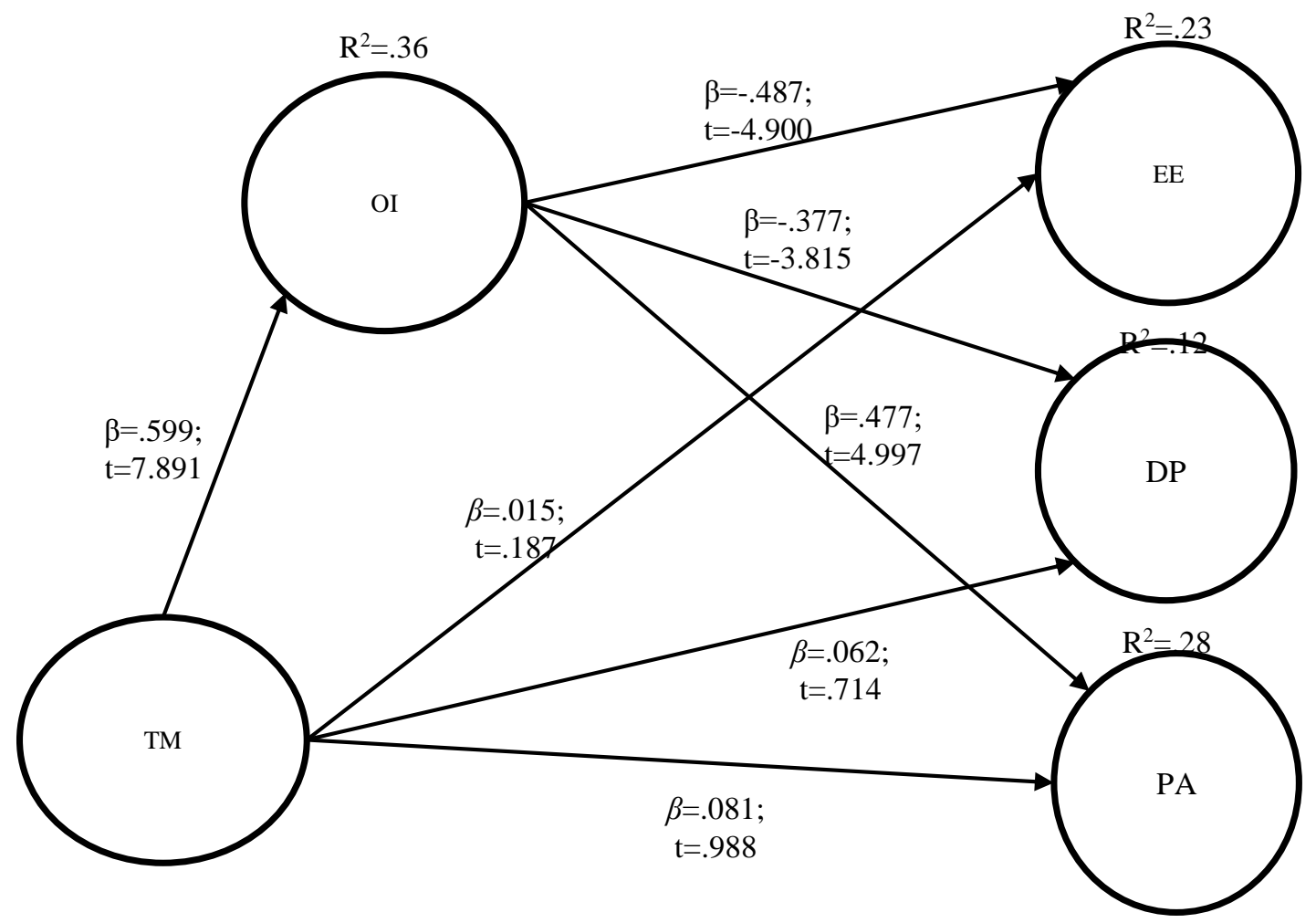

Goodness- of- fit statistics: $\chi 2 / \mathrm{df}=2.373 ; \mathrm{IFI}=.90 ; \mathrm{CFI}=.90 ; \mathrm{GFI}=.84 ; \mathrm{RMSEA}=.07$, OI: Organizational identification, TM: Trust in manager, EE: Emotional exhaustion, DP: Depersonalization, PA: Personal accomplishment.

\section{Figure 1. Structural Model Results}

\section{3. Mediating Effect of Organizational Identification}

Bootstrap confidence intervals method was used to test the mediation effect (Hayes, 2013, p. 197). Firstly, a model where organizational identification is excluded was created to test the direct effect of trust in manager on burnout. As shown in Table 3, trust in manager negatively and significantly affects the variables of burnout, emotional exhaustion and depersonalization, while it positively and significantly affects personal accomplishment $(\beta=-.292 ; \mathrm{t}=-4.237 ; \mathrm{p}<.001 ; \beta=-.177 ; \mathrm{t}=-2.634 ; \mathrm{p}$ $<.01 ; \beta=.378 ; \mathrm{t}=5.499 ; \mathrm{p}<.001)$. Then, the mediation role of organizational identification was analyzed through the bootstrap method. Because the bootstrap method provides the strongest and most reasonable reliability limits for certain indirect effects under many conditions (Preacher and Hayes, 2008). Thus, bias-corrected (BC) bootstrap method was carried out as it is one of the commonly used and mostly recommended methods (Hayes, 2009; MacKinnon et al., 2004; Lederman and Macho, 2009; Williams and MacKinnon, 2008). The BC bootstrap method requires a certain number of subsamples. So, 1000 sub-samples were determined following the recommendations in the literature (Cheung and Lau, 2008) and the method was conducted. The results of the mediation role of organizational identification are depicted in Table 3. 
Table 3. Standardized Indirect and Total Effects

\begin{tabular}{lllll}
\hline Hypotheses & Relations & $\begin{array}{l}\text { Without } \\
\text { organizational } \\
\text { identification }(\beta)\end{array}$ & $\begin{array}{l}\text { With organizational } \\
\text { identification }(\beta)\end{array}$ & Result \\
\hline $\mathrm{H} 4 \mathrm{a}$ & $\mathrm{TM} \rightarrow \mathrm{EE}$ & $-.292^{* * *}$ & .015 & Fully mediated \\
$\mathrm{H} 4 \mathrm{~b}$ & $\mathrm{TM} \rightarrow \mathrm{DP}$ & $-.177^{* *}$ & .062 & Supported \\
$\mathrm{H} 4 \mathrm{c}$ & $\mathrm{TM} \rightarrow \mathrm{PA}$ & $.378^{* * *}$ & .081 & $\mathrm{TM} \rightarrow \mathrm{PA}$ \\
\hline Confidence intervals of the mediation & $\mathrm{TM} \rightarrow \mathrm{EE}$ & $\mathrm{TM} \rightarrow \mathrm{DP}$ & .145 \\
\hline \multicolumn{7}{c}{} \\
\multicolumn{7}{l}{ Confidence } \\
intervals & Lower bound & -.478 & -.405 & .443 \\
& Upper bound & -.170 & -.101 & $.285^{* *}$
\end{tabular}

${ }^{* * *} \mathrm{p}<.001 ;{ }^{* *} \mathrm{p}<.01$ OI: Organizational identification, TM: Trust in manager, EE: Emotional exhaustion, DP: Depersonalization, PA: Personal accomplishment

Organizational identification fully mediates the relationship between trust in manager and burnout variables, emotional exhaustion, depersonalization and personal accomplishment. The indirect effect of organizational identification on the relationship between trust in manager and emotional exhaustion and depersonalization is below zero and between the lower and upper bounds. Besides its indirect effect on the relationship between trust in manager and personal accomplishment is over zero and between the boundaries (see Table 3). Furthermore, the fact that indirect effect of organizational identification on the relationship between trust in manager and the dimensions of burnout significantly confirms the mediating role of organizational identification, respectively $(\beta=-.292 ; \mathrm{p}$ $<.01 ; \beta=-.226 ; p<.01 ; \beta=.285 ; \mathrm{p}<.01$ ). Therefore, the findings support Hypotheses $4 \mathrm{a}$, $4 \mathrm{~b}$ and $4 \mathrm{c}$. Depending on these findings, it is inferred that when organizational identification is involved, it plays a critical role to reduce emotional exhaustion and depersonalization levels of the employees. Moreover, it is also possible to suggest that it plays a decisive role in personal accomplishment.

\section{DISCUSSION AND IMPLICATIONS}

In this study, 272 educators working in the state high schools in Nevşehir province were taken as sample, and trust in manager, organizational identification and burnout variables in the developed model were empirically examined based on the theoretical foundations. The findings prove that goodness-of-fit indices of the model were within acceptable limits and the construct validity (discriminant and convergent validity) of the model was also provided. So we have reliable grounds to suggest some theoretical and practical implications relying on the findings.

\section{1. Theoretical Implications}

This study has some theoretical implications. First, the positive relationship between trust in manager and organizational identification coincide with the findings of many theoretical and empirical studies in the literature. Trust in manager is considered as one of the dimensions of organizational trust (Agarwal, 2013; Tokgöz and Seymen, 2013). However, it is also seen that trust in manager is handled with different titles such as trust in leader, pioneer principals. In these studies, it is argued there is a positive and significant relationship between trust in manager and organizational identification (Connaughton and Daly, 2004; De Cremer and van Knippenberg, 2005; Agarwal, 2013). In addition, there are studies, which address trust in manager with a cognitive-based and emotion-based trust in leader. In these studies, the findings also provide a positive and significant relationship between trust in leader and organizational identification (Ertürk, 2010; Schaubroeck et al., 2013). It is stated that organizational identification decreases the effect of negative organizational outputs such as intention to leave and burnout, and increases positive organizational outcomes such as job satisfaction, organizational citizenship and performance (Wegge et al., 2006; Riketta and Van Dick, 2005). Therefore, it is possible to suggest that trust in manager will contribute to the positive effects of 
organizational identification on organizational performance.

Secondly, the research findings indicate that trust in manager negatively affects emotional exhaustion and depersonalization, whereas personal accomplishment is positively affected. In parallel with this finding, Çağlar (2011) and Son et al. (2014) argue that there is a negative and significant relationship between trust in manager and emotional exhaustion and depersonalization in their studies. Van Maele and Van Houtte (2015) report a negative relationship between trust in school principal and emotional exhaustion, depersonalization and reduced personal accomplishment. Moreover, it is reported that trust in leader negatively affects perceived burnout (Harvey et al., 2003; Mo and Shi, 2017). In addition, it is stated that there is a significant relationship between trust in manager/principal and burnout and the employees with low level of trust may experience a higher level of burnout (Ceyanes, 2004). However, structural model results show that when organizational identification is included in the model, the effect of trust in manager is not significant. Therefore, it is possible to interpret the finding that trust in manager is not effective in reducing the negative effect of emotional exhaustion and depersonalization on workers. In addition, trust in manager does not increase personal accomplishment when it comes to organizational identification. So, organizational identification plays a decisive role in reducing or eliminating the impact of emotional exhaustion and depersonalization on teachers, but it increases their personal accomplishment

Theoretically, the third contribution of this study is the examination of the relationship between organizational identification and burnout. It affects negatively emotional exhaustion and depersonalization but positively personal accopmlishment. In parallel with this finding, Rode et al. (2012) argue that there is a negative and significant relationship between organizational identification and burnout. Avanzi et al. (2015) report that organizational identification negatively affects emotional exhaustion and reduced personal accomplishment. In addition, Kemp et al. (2013) have found a negative and significant relationship between organizational identification and emotional exhaustion, and Wegge et al. (2006) and Lammers et al. (2013) verify that organizational identification negatively and significantly affects emotional exhaustion and depersonalization. In addition, Wegge et al. (2006) clarify the positive relationship between organizational identification and personal accomplishment. It is seen that these findings in the literature correspond to the findings of this study. Thus, it is concluded that organizational identification will play an important role in reducing burnout, which has many negative personal, social and organizational outputs (Maslach and Leiter, 2017). In other words, the negative organizational outputs such as the amount of absenteeism wish, intention to leave, low service quality and performance and the number of occupational accidents can be minimized through the reduction of burnout level (Maslach and Leiter, 2008).

The final theoretical contribution of this study is that it examines the mediating role of organizational identification on the relationship between trust in manager and burnout. They are fully mediated by organizational identification. We expected that organizational identification would act as a mediator between trust in manager and burnout because trust in manager increases the level of organizational identification (Connaughton and Daly, 2004; De Cremer and van Knippenberg, 2005; Agarwal, 2013). Organizational identification leads to job satisfaction (Wegge et al., 2006), provides more work inputs, decreases the intention to leave (Lee, 1971) and decreases burnout (Maslach et al., 2001). We found that it fully mediated the relationship between trust in manager and burnout. So, teachers' perception of organizational identification plays a serious role in reducing their emotional exhaustion and depersonalization levels. It also plays a decisive role in their personal achievement in this equation. This mediating role of organizational identification between trust in manager and burnout will not only reduce the negative outcomes of burnout but also it will contribute to teacher satisfaction, performance, and extra efforts for school goals.

\section{2. Practical Implications}

One of the most important inputs of educational organizations is human resources as they are servicebased institutions. Teachers and principals are the practitioners of the strategies and tactics that schools set for the goals. This study offers some suggestions to these practitioners. The results of the study show that there is a positive relationship between trust in manager and organizational identification. It is a prerequisite for teachers to trust their principals to strengthen their level of organizational identification. The following recommendations are made to ensure this prerequisite. 
First, awareness can be created so that the school skills - teachers' abilities, the number of the students who are placed in a faculty at a university, social and sports facilities and success and so forth- are sufficient to sustain school development. So, training, conferences, seminars, etc. can be held to develop and continuously improve both educators and school skills. At this stage, the phenomena of principals and teachers' taking responsibility for the problems, mistakes and violations can play an important role in the levels of organizational identification. Second, it may be useful to see the skills and values in educators and give importance to the work inputs that they provide and they should be meaningfully awarded. Third, the establishment of easy accessibility and use of information along with the understanding of transparency and openness at schools, and allowing the educators to express their thoughts freely during the decision stage can contribute to the level of organizational identification. In addition, it can be effective to establish a clear and healthy communication network and provide feedback on problem solving initiatives and sort out the situations that would lead to a breach of trust. Fourth, deployment of the factors such as security, protection, assurance and tolerance in school policies can help to create organizational identification. In this process, it will be appropriate that the pricipals show attitudes and behaviors that their welfare and interests will be protected. Fifth, the establishment of equality and justice at schools, the implementation of fair policies, and the consistency between principals' practices and words can help to strengthen organizational identification. Finally, taking measures to prevent potential deviations in job responsibilities and jurisdictions can also contribute the organizational identification. It is also necessary to eliminate the attitudes, which underestimate teachers' potentials and skills. Furthermore, utmost attention should be paid to system and process changes that may lead to trust breaches and it is also required to eliminate structural deficiencies, which may be effective in increasing and maintaining organizational identification.

The results of the study suggest that schools and principals should pay attention to organizational identification to lessen burnout and its full mediation role between trust in manager and burnout. In this sense, in order to reduce burnout, the following managerial implications can be suggested within the scope of organizational identification. First, school goals and teachers' goals should be harmonized. Organizational attractiveness can be increased by having teachers to feel loyalty to the school. For this purpose, firstly, shared features can be created by emphasizing the similarity of the qualifications between teachers within the organization. By setting shared and common objectives, teachers can be supported to contribute to the goals, to be proud of their membership and to tend to defend the school against the internal and external environment. Secondly, integration with the school can be ensured by the adoption of common norms and values, thus it will be possible to create an emotional commitment to the school. It is possible to form solidarity and unity through these ties and so, teachers may start to feel that they are the members of a special structure. In addition, organizational identity should be characterized and well clarified from other social identities. Thus, it can be ensured that school employees define themselves in line with school characteristics. Finally, practitioners should also pay attention to the hazard of negative stereotyping about the internal group and the external group and particularly internal group favoritism because they lead to polarization. From this point of view, organizational identification should be created in a strong and distinct manner. It can be stated that the burnout levels of teachers, which lead many negative personal, social and organizational results, can be overcome.

\section{3. Limitation and Future Research}

This study also has some limitations like nearly in all studies. It only considers the state high schools in Nevşehir. The educators working in primary schools, kindergartens and private schools are not included. Therefore, research findings cannot be generalized for all schools, educational institutions and regions. The other limitation is that the study is based on a cross sectional design. The data set represents the perception of participants at a given period and so, the findings refer to those perceptions. In addition, Karazsia and Berlin (2018) state that time plays a critical role to decide the third variable as a moderator or a mediator. In cross-sectional studies, it is very difficult to verify the tests of mediation models because mediation tests require multible timepoints because mediators are both criterions and casual predictors (Karazsia and Berlin, 2018). So, this is an other shortcoming of the study. Future studies should be performed in a longitudinal design. Another limitation is the likelihood of social desirability. It may play a role especially when the variables are considered. 
Common method variance may occur when various variables are evaluated in the same period by the same respondents. Therefore, it should not be ignored that the variance of common method may influence the strength of relationship between the variables. To avaoid the negative reflections of this method, data can be collected from different sources in future studies. New studies on these variables will contribute to the literature. Also, it may be suggested to include the group or team trust and team identification dimensions in the sample where group or team work is done.

\section{REFERENCES}

Agarwal, V. (2013). Investigating the Convergent Validity of Organizational Trust, Journal of Communication Management, 17(1): 24-39.

Anderson, J.C. \& Gerbing, D.W. (1988). Structural Equation Modeling in Practice: A Review and Recommended Two-Step Approach, Psychological Bulletin, 103(3): 411-423.

Ashforth, B.E., Harrison, S.H. \& Corley, K.G. (2008). Identification in Organizations: An Examination of Four Fundamental Questions, Journal of Management, 34(3): 325-374.

Avanzi, L., Schuh, S.C., Fraccaroli, F. \& Van Dick, R. (2015). Why Does Organizational Identification Relate To Reduced Employee Burnout? The Mediating Influence of Social Support and Collective Efficacy, Work \& Stress, 29(1): 1-10.

Baer, M.D., Dhensa-Kahlon, R.K., Colquitt, J.A., Rodell, J.B., Outlaw, R. \& Long, D.M. (2015). Uneasy Lies the Head That Bears the Trust: The Effects of Feeling Trusted on Emotional Exhaustion, Academy of Management Journal, 58(6): 1637-1657.

Bianchi, R., Schonfeld, I.S. \& Laurent, E. (2015). Interpersonal Rejection Sensitivity Predicts Burnout: A Prospective Study, Personality and Individual Differences, 75, 216-219.

Biçkes, D.M. \& Yılmaz, C. (2017). Örgütsel Özdeşleşmenin Tükenmişlik Üzerindeki Etkisi: Öğretmenler Üzerinde Bir Uygulama, Is, Guc: The Journal of Industrial Relations \& Human Resources, 19(2): 91-110.

Blankertz, L.E. \& Robinson, S.E. (1997). Turnover Intentions of Community Mental Health Workers in Psychosocial Rehabilitation Services, Community Mental Health Journal, 33(6): 517-529.

Bobbio, A., Bellan, M. \& Manganelli, A.M. (2012). Empowering Leadership, Perceived Organizational Support, Trust, and Job Burnout for Nurses: A Study in an Italian General Hospital, Health Care Management Review, 37(1): 77-87.

Bowen, N.K. \& Guo, S. (2011). Structural Equation Modeling, Oxford University Press, New York.

Braun, S., Peus, C., Weisweiler, S. \& Frey, D. (2013). Transformational Leadership, Job Satisfaction, and Team Performance: A Multilevel Mediation Model of Trust, The Leadership Quarterly, 24(1): 270-283.

Brower, H.H., Lester, S.W., Korsgaard, M.A. \& Dineen, B.R. (2009). A Closer Look at Trust between Managers and Subordinates: Understanding the Effects of Both Trusting and Being Trusted on Subordinate Outcomes, Journal of Management, 35(2): 327-347.

Byrne, B.M. (2010). Structural Equation Modeling With Amos: Basic Concepts, Applications, and Programming, $2^{\text {nd }}$ Ed., Routledge, New York.

Ceyanes, J.W. (2004). "An Analysis Between Teacher Trust in the Principal and Teacher Burnout as Identified by Teachers in Selected Texas Public Schools", Doctoral Dissertation, A\&M University, Texas.

Cheung G.W. \& Lau, R.S. (2008). Testing Mediation and Suppression Effects of Latent Variables: Bootstrapping with Structural Equation Models, Organizational Research Methods, 11(2): 296325.

Cohen, A. \& Eyal, O. (2015). The Role of Organizational Justice and Exchange Variables in Determining Organizational Citizenship Behavior Among Arab Teachers in Israel, Psychological Studies, 60(1): 56-69. 
Cohen, M.A. \& Dienhart, J. (2013). Moral and Amoral Conceptions of Trust, With an Application in Organizational Ethics, Journal of Business Ethics, 112(1): 1-13.

Connaughton, S.L. \& Daly, J.A. (2004). Identification with Leader: A Comparison of Perceptions of Identification Among Geographically Dispersed and Co-Located Teams, Corporate Communications: An International Journal, 9(2): 89-103.

Çağlar, Ç. (2011). Okullardaki Örgütsel Güven Düzeyi ile Öğretmenlerin Mesleki Tükenmişlik Düzeyinin Bazı Değişkenler Açısından Incelenmesi, Kuram Ve Uygulamada Eğitim Bilimleri, 11(4): 1827-1847.

De Cremer, D. \& Van Knippenberg, D. (2005). Cooperation as Afunction of Leaderself-Sacrifice, Trust, and Identification, Leadership \& Organization Development Journal, 26(5): 355-369.

De Francisco, C., Arce, C., Del Pilar Vílchez, M. \& Vales, Á. (2016). Antecedents and Consequences of Burnout in Athletes: Perceived Stress and Depression, International Journal of Clinical and Health Psychology, 16(3): 239-246.

Demircan, N. (2003). “Örgütsel Güvenin Bir Ara Değișken Olarak Örgütsel Bağlilik Üzerindeki Etkisi: Eğitim Sektöründe Bir Uygulama”, Yayımlanmamış Doktora Tezi, Doctoral Thesis, Gebze İleri Teknoloji Enstitüsü, Sosyal Bilimler Enstitüsü, Gebze.

Diamantopoulos, A. \& Siguaw, J.A. (2000). Introducing Lisrel: A Guide For The Uninitiated. Sage Publications, London.

Dovey, K. (2009). The Role of Trust in Innovation, The Learning Organization, 16(4): 311-325.

Dutton, J.E., Dukerich, J. M. \& Harquail, C.V. (1994). Organizational Images and Member Identification, Administrative Science Quarterly, 39(2): 239-263.

Dyer, J.H. \& Chu, W. (2003). The Role of Trustworthiness in Reducing Transaction Costs and Improving Performance: Empirical Evidence from The United States, Japan, and Korea, Organization Science, 14(1): 57-68.

Edwards, J.R. \& Cable, D.M. (2009). The Value of Value Congruence, Journal of Applied Psychology, 94(3): 654-677.

Edwards, M.R. (2006). Organizational Identification: A Conceptual and Operational Review, International Journal of Management Reviews, 7(4)::207-230.

Edwards, M.R. \& Peccei, R. (2010). Perceived Organizational Support, Organizational Identification, and Employee Outcomes, Journal of Personnel Psychology, 9(1): 17-26.

Eğriboyun, D. (2013). Ortaöğretim Okullarında Görev Yapan Yönetici Ve Öğretmenlerin Örgütsel Güven ve Örgütsel Destek Algıları Arasındaki Ilişki, Kafkas Üniversitesi Sosyal Bilimler Enstitüsü Dergisi, 1(12): 17-43.

Ellonen, R., Blomqvist, K. \& Puumalainen, K. (2008). The Role of Trust in Organisational İnnovativeness, European Journal of Innovation Management, 11(2): 160-181.

Ergin, C. (1992). “Doktor ve Hemşirelerde Tükenmişlik ve Maslach Tükenmişlik Ölçeği'nin Uyarlanmasi”, (Ed.: Bayraktar, R. Ve Dağ, İ.), 7. Ulusal Psikoloji Kongresi Bilimsel Çalışmaları, ss. 143-154. Hacettepe University, Ankara.

Ertürk, A. (2010). Exploring Predictors of Organizational Identification: Moderating Role of Trust on the Associations Between Empowerment, Organizational Support, and Identification, European Journal of Work and Organizational Psychology, 19(4): 409-441.

Esitti, B. \& Akyüz, B. (2015). Konaklama Isletmelerinde Mobbing-Örgütsel Güven Iliskisi: Çanakkale Ilinde Bir Arastirma, Selcuk Üniversitesi Sosyal Bilimler Enstitüsü Dergisi, 34: 1-15.

Fornell, C. \& Larcker, D.F. (1981). Evaluating Structural Equation Models with Unobservable Variables and Measurement Error, Journal of Marketing Research, 18(1): 39-50.

Freudenberger, H.J. (1974). Staff Burnout, Journal of Social Issues, 30(1): 159-165. 
Fu, H., Ye, B.H. \& Law, R. (2014). You Do Well and I Do Well? The Behavioral Consequences of Corporate Social Responsibility, International Journal of Hospitality Management, 40: 62-70.

Fulmer, C.A. \& Gelfand, M.J. (2012). At What Level (and in Whom) We Trust: Trust Across Multiple Organizational Levels, Journal of Management, 38(4): 1167-1230.

Gaskin, J. \& Lim, J. (2016). Master Validity Tool: AMOS Plugin, Gaskination's Statwiki.

Hair, J.F, Black, W.C, Babin, B.J. \& Anderson, R.E. (2013). Multivariate Data Analysis: Pearson New International Edition, 7th Ed., Pearson Education Limited, Essex.

Haque, F. (2014). Education For Sustainable Development: An Evaluation of the New Curriculum of The Formal Primary Education in Bangladesh, European Scientific Journal, ESJ, 9(10): 320-330.

Harvey, S., Kelloway, E.K. \& Duncan-Leiper, L. (2003). Trust in Management as a Buffer of the Relationships between Overload and Strain, Journal of Occupational Health Psychology, 8(4): 306-315.

Hashemi, S.A. \& Kohestani, M. (2016). Investigating the Relationship Between Transformational Management Style and Teachers Knowledge Sharing in Schools of Mohr City in the Academic Year 2016-2015, Iioab Journal, 7(4): 362-366.

Haslam, S.A. (2004). Psychology in Organizations: The Social Identity Approach, Sage Publications, London.

Hayes, A.F. (2009). Beyond Baron and Kenny: Statistical Mediation Analysis in The New Millennium, Communication Monographs, 76(4): 408-420.

Hayes, A.F. (2013). Introduction to Mediation, Moderation, and Conditional Process Analysis: A Regression-Based Approach, Guilford Publications, New York.

He, H., Zhu, W. \& Zheng, X. (2014). Procedural Justice and Employee Engagement: Roles of Organizational Identification and Moral Identity Centrality, Journal of Business Ethics, 122(4): 681-695.

Hu, L.T. \& Bentler, P.M. (1999). Cutoff Criteria for Fit Indexes in Covariance Structure Analysis: Conventional Criteria versus New Alternatives, Structural Equation Modeling: A Multidisciplinary Journal, 6(1): 1-55.

Karabey, C.N. \& İşcan, Ö.F. (2007). Örgütsel Özdeşleşme, Örgütsel Imaj ve Örgütsel Vatandaşlık Davranışı Ilişkisi: Bir Uygulama, Íktisadi ve İdari Bilimler Dergisi, 21(2): 231-241.

Karazsia, B. T. \& Berlin, K. S. (2018). Can A Mediator Moderate? Considering The Role of Time and Change in The Mediator-Moderator Distinction, Behavior Therapy, 49(1): 12-20.

Kauts, A. \& Sharma, G. (2017). Leadership Effectiveness and Teacher's Job Satisfaction in Relation to School Effectiveness at Secondary Stage, MIER Journal of Educational Studies, Trends and Practices, 7(1): 1-13.

Kemp, E., Kopp, S.W. \& Kemp, E.C. (2013). Take This Job and Shove It: Examining the Influence of Role Stressors Aand Emotional Exhaustion on Organizational Commitment and Identification in Professional Truck Drivers, Journal of Business Logistics, 34(1): 33-45.

Khattak, M.N., Shah, T.A. \& Said, B. (2014). Significant Predictor and Outcome of Interpersonal Trust: Empirical Evidence from Pakistan, International Journal of Information, Business and Management, 6(2): 153-168.

Kitchenham B. \& Pfleeger, S.L. (2002). Principles of Survey Research: Part 5: Populations and Samples, ACM SIGSOFT Software Engineering Notes, 27(5): 17-20.

Kline, R.B. (2011). Principles and Practice of Structural Equation Modeling, 3 ${ }^{\text {rd }}$ Ed., Guilford Press. New York.

Kline, R.B. (2016). Principles and Practice of Structural Equation Modeling, 4th Ed., Guilford Press, New York. 
Korunka, C., Tement, S., Zdrehus, C. \& Borza, A. (2010). Burnout: Definition, Recognition and Prevention Approaches. Boit.

Lammers, J.C., Atouba, Y.L. \& Carlson, E.J. (2013). Which Identities Matter? A Mixed-Method Study of Group, Organizational, and Professional Identities and Their Relationship to Burnout, Management Communication Quarterly, 27(4): 503-536.

Ledermann, T. \& Macho, S. (2009). Mediation in Dyadic Data at the Level of the Dyads: A Structural Equation Modeling Approach, Journal of Family Psychology, 23(5): 661-670.

Lee, A.N. \& Nie, Y. (2017). Teachers' Perceptions of School Leaders' Empowering Behaviours and Psychological Empowerment: Evidence From a Singapore Sample, Educational Management Administration \& Leadership, 45(2): 260-283.

Lee, E.S., Park, T.Y. \& Koo, B. (2015). Identifying Organizational Identification As a Basis for Attitudes and Behaviors: A Meta-Analytic Review, Psychological Bulletin, 141(5): 1049-1080.

Lee, H.J. (2004). The Role of Competence-Based Trust and Organizational Identification in Continuous İmprovement, Journal of Managerial Psychology, 19(6): 623-639.

Lee, S.M. (1971). An Empirical Analysis of Organizational Identification, Academy of Management Journal, 14(2): 213-226.

Levine, M., Prosser, A., Evans, D. \& Reicher, S. (2005). Identity and Emergency İntervention: How Social Group Membership and İnclusiveness of Group Boundaries Shape Helping Behavior, Personality and Social Psychology Bulletin, 31(4): 443-453.

Lewicki, R.J. \& Bunker, B.B. (1996). "Developing and Maintaining Trust in Work Relationships”, (Ed.: Kramer, R.M. And Tyler, T.R.), pp. 114-139, Trust in Organizations: Frontiers of Theory and Reach, Sage Publications, London.

Mackinnon, D.P., Lockwood, C.M. \& Williams, J. (2004). Confidence Limits for The Indirect Effect: Distribution of The Product and Resampling Methods, Multivariate Behavioral Research, 39(1): 99-128.

Mael, F. \& Ashforth, B.E. (1992). Alumni and Their Alma Mater: A Partial Test of the Reformulated Model of Organizational Identification, Journal of Organizational Behavior, 13(2): 103-123.

Maslach, C. (1976). Burned-Out, Human Behavior, 5(9): 16-22.

Maslach, C. \& Jackson, S. E. (1981). The Measurement of Experienced Burnout, Journal of Occupational Behavior, 2(2): 99-113.

Maslach, C. \& Leiter, M.P. (2017). New Insights Into Burnout And Health Care: Strategies for Improving Civility and Alleviating Burnout, Medical Teacher, 39(2): 160-163.

Maslach, C. \& Leiter; M.P. (2008). The Truth About Burnout: How Organizations Cause Personal Stress And What To Do About It. John Wiley \& Sons, San Francisco.

Maslach, C. \& Schaufeli, W.B. (2017). "Historical and Conceptual Development Of Burnout", (Ed.: Wilmar B. Schaufeli, W.B., Maslach, C. \& Marek, T.), pp. 1-16, Professional Burnout Recent Developments In Theory And Research, Routledge. London and New York.

Maslach, C., Schaufeli, W.B. \& Leiter, M.P. (2001). Job Burnout, Annual Review of Psychology, 52(1): 397422.

Mayer, R.C., Davis, J.H. \& Schoorman, F.D. (1995). An Integrative Model of Organizational Trust, Academy of Management Review, 20(3): 709-734.

Mignonac, K., Herrbach, O. \& Guerrero, S. (2006). The Interactive Effects of Perceive Dexternal Prestige and Need For Organizational Identification on Turnover Intentions, Journal of Vocational Behavior, 69(3): 477-493.

Mishra, A.K. (1996). “Organizational Responses to Crisis: The Centrality of Trust”, (Ed.: Kramer, R.M. And Tyler, T.R.), pp. 261-287, Trust in Organizations: Frontiers of Theory and Reach, Sage Publication, London. 
Mo, S. \& Shi, J. (2017). Linking Ethical Leadership to Employee Burnout, Workplace Deviance and Performance: Testing the Mediating Roles of Trust in Leader and Surface Acting, Journal of Business Ethics, 144(2): 293-303.

Morçin, S.E. \& Çarıkçı, İ.H. (2016). Dönüştürücü/Etkileşimci Liderliğin Iş Tatminine Etkisinde Örgütsel Özdeşleşmenin Aracilik Rolü: Antalya'daki Beş Yıldızlı Otel Işletmeleri Örneği, Süleyman Demirel Üniversitesi Íktisadi ve İdari Bilimler Fakültesi Dergisi, 21(1): 97-112.

Moriano, J.A., Molero, F., Topa, G. \& Mangin, J.P.L. (2014). The Influence of Transformational Leadership and Organizational Identification on Intrapreneurship, International Entrepreneurship and Management Journal, 10(1): 103-119.

Nevşehir İl Milli Eğitim Müdürlüğü, (2014). Okullar ve Diğer Kurumlar, Available At Http://www.meb.gov.tr/Baglantilar/Okullar/Index.Php?ILKODU=50, (Accessed 17 February 2014).

Nyhan, R.C. \& Marlowe, H.A. (1997). Development and Psychometric Properties of the Organizational Trust Inventory, Evaluation Review, 21(5): 614-635.

O'Neill, J. L. \& Gaither, C. A. (2007). Investigating The Relationship Between The Practice of Pharmaceutical Care, Construed External Image, Organizational Identification, and Job Turnover Intention of Community Pharmacists, Research in Social and Administrative Pharmacy, 3(4): 438-463.

Özafşarlığlu Sakallı, S. \& Örücü, E.(2017). Örgütsel Adalet ile Örgütsel Güven İlişsisinde Kişilik Özelliklerinin Düzenleyici Rolü ve Bir Alan Araştırması, International Journal of Academic Value Studies, 3(16): 214-236.

Özan, M.B. \& Özdemir, T.Y. (2013). İlköğretim Kurumu Öğretmenlerinin Örgütsel Güven Düzeyleri: Nitel Bir Çalışma, Gaziantep University Journal of Social Sciences, 12(3): 469-486.

Podsakoff, P.M. \& Organ, D.W. (1986). Self-Reports in Organizational Research: Problems and Prospects, Journal Of Management, 12(4): 531-544.

Preacher, K.J. \& Hayes, A.F. (2008). Asymptotic and Resampling Strategies for Assessing and Comparing Indirect Effects in Multiple Mediator Models, Behavior Research Methods, 40(3): 879-891.

Rabasa, B., Figueiredo-Ferraz, H., Gil-Monte, P.R. \& Llorca-Pellicer, M. (2016). The Role of Guilt in The Relationship between Teacher's Job Burnout Syndrome and the Inclination toward Absenteeism, Revista De Psicodidáctica, 21(1): 103-119.

Richardsen, A.M. \& Burke, R.J. (1995). Models of Burnout: Implications for Interventions, International Journal of Stress Management, 2(1): 31-43.

Riketta, M. (2005). Organizational Identification: A Meta-Analysis, Journal of Vocational Behavior, 66(2): 358-384.

Riketta, M. \& Van Dick, R. (2005). Foci of Attachment in Organizations: A Meta-Analytic Comparison of the Strengt Hand Correlates of Workgroup versus Organizational Identification and Commitment, Journal of Vocational Behavior, 67(3): 490-510.

Rode, J.C., Judge, T.A. \& Sun, J.M. (2012). Incremental Validity of Core Self-Evaluations in The Presence of Other Self-Concept Traits an Investigation of Applied Psychology Criteria in the United States and China, Journal of Leadership \& Organizational Studies, 19(3): 326-340.

Rousseau, D.M., Sitkin, S.B., Burt, R.S. \& Camerer, C. (1998). Not So Different After All: A CrossDiscipline View of Trust, Academy of Management Review, 23(3): 393-404.

Salvagioni, D.A.J., Melanda, F.N., Mesas, A.E., González, A.D., Gabani, F.L. \& De Andrade, S.M. (2017). Physical, Psychological and Occupational Consequences of Job Burnout: A Systematic Review of Prospective Studies, Plos One, 12(10): 1-29. 
Schaubroeck, J.M., Peng, A.C. \& Hannah, S.T. (2013). Developing Trust with Peers and Leaders: Impacts on Organizational Identification and Performance During Entry, Academy of Management Journal, 56(4): 1148-1168.

Schermelleh-Engel, K., Moosbrugger, H. \& Müller, H. (2003). Evaluating The Fit of Structural Equation Models: Tests of Significance and Descriptive Goodness-Of-Fit Measures, Methods of Psychological Research Online, 8(2): 23-74.

Schumacker, R.E. \& Lomax, R.G. (2016). A Beginner's Guide to Structural Equation Modeling, 4th Ed., Routledge Psychology Press, New York.

Shen, B., Mccaughtry, N., Martin, J., Garn, A., Kulik, N. \& Fahlman, M. (2015). The Relationship Between Teacher Burnout and Student Motivation, British Journal Of Educational Psychology, 85(4): 519532.

Sirén, C., Patel, P.C., Örtqvist, D. \& Wincent, J. (2018). CEO Burnout, Managerial Discretion, and Firm Performance: The Role of CEO Locus of Control, Structural Power, and Organizational Factors, Long Range Planning, 51(6): 953-971.

Skaalvik, E.M. \& Skaalvik, S. (2017). Dimensions of Teacher Burnout: Relations With Potential Stressors at School, Social Psychology Of Education, 20(4): 775-790.

Son, S., Kim, D.Y. \& Kim, M. (2014). How Perceived Interpersonal Justice Relates to Job Burnout and Intention to Leave: The Role of Leader-Member Exchange and Cognition-Based Trust in Leaders, Asian Journal of Social Psychology. 17(1): 12-24.

Tan, H.H. \& Tan, C.S. (2000). Toward The Differentiation of Trust in Supervisor and Trust in Organization, Genetic, Social, and General Psychology Monographs, 126(2): 241-260.

Tokgöz, E. \& Seymen, O.A. (2013). Örgütsel Güven, Örgütsel Özdeşleşme Ve Örgütsel Vatandaşlık Davranışı Arasındaki Ilişki: Bir Devlet Hastanesinde Araştırma, Öneri Dergisi, 10(39): 61-76.

Tüzün, İ.K. \& Çağlar, İ. (2009). Investigating the Antecedents of Organizational Identification, Doğuş Üniversitesi Dergisi, 10(2): 284-293.

Van Dick, R., Wagner, U., Stellmacher, J. \& Christ, O. (2004). The Utility of a Broader Conceptualization of Organizational Identification: Which Aspects Really Matter? Journal of Occupational and Organizational Psychology, 77(2): 171-191.

Van Maele, D. \& Van Houtte, M. (2015). Trust in School: A Pathway to İnhibit Teacher Burnout? Journal Of Educational Administration, 53(1): 93-115.

Wadhwa, S. \& Tripathi, R. (2018). Driving Employee Performance Through Talent Management, International Journal Of Environment, Workplace And Employment, 4(4): 288-313.

Wegge, J., Vandick, R., Fisher, G.K., Wecking, C. \& Moltzen, K. (2006). Work Motivation, Organisational Identification, and Well-Being in Call Centre Work, Work \& Stress, 20(1): 60-83.

Williams, J. \& Mackinnon, D.P. (2008). Resampling and Distribution of The Product Methods for Testing Indirect Effects in Complex Models", Structural Equation Modeling: A Multidisciplinary Journal, 15(1): 23-51.

Yazıcıoğlu, Y. \& Erdoğan, S. (2004). SPSS Uygulamalı Bilimsel Araştırma Yöntemleri, Detay Yayıncılık, Ankara.

Yıldız, E. (2012). Mesleki Tükenmişlik ve Rehber Öğretmenler Üzerine Bir Araştırma, Erciyes Üniversitesi SBE Dergisi, 33(2): 37-61. 